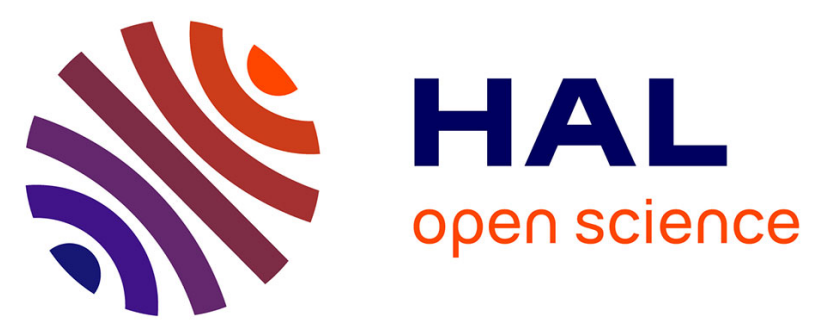

\title{
Soil organic matter (SOM) characterization by Rock-Eval pyrolysis : scope and limitations
}

\author{
Jean-Robert Disnar, Bernard Guillet, Didier Kéravis, Christian Di Giovanni,
} David Sebag

\section{- To cite this version: \\ Jean-Robert Disnar, Bernard Guillet, Didier Kéravis, Christian Di Giovanni, David Sebag. Soil organic matter (SOM) characterization by Rock-Eval pyrolysis : scope and limitations. Organic Geochemistry, 2003, 34, pp.327-343. 10.1016/S0146-6380(02)00239-5 . hal-00069394}

HAL Id: hal-00069394

https://hal-insu.archives-ouvertes.fr/hal-00069394

Submitted on 20 Jun 2013

HAL is a multi-disciplinary open access archive for the deposit and dissemination of scientific research documents, whether they are published or not. The documents may come from teaching and research institutions in France or abroad, or from public or private research centers.
L'archive ouverte pluridisciplinaire $\mathbf{H A L}$, est destinée au dépôt et à la diffusion de documents scientifiques de niveau recherche, publiés ou non, émanant des établissements d'enseignement et de recherche français ou étrangers, des laboratoires publics ou privés.

\section{(ㅇ)(1) $\$$}

Distributed under a Creative Commons Attribution - NonCommercial - NoDerivatives| 4.0 


\title{
Soil organic matter (SOM) characterization by Rock-Eval pyrolysis: scope and limitations
}

\author{
J.R. Disnar ${ }^{\mathrm{a}}$ \\ B. Guillet ${ }^{\mathrm{a}}$ \\ D. Keravis ${ }^{\mathrm{a}}$ \\ C. Di-Giovanni ${ }^{\mathrm{a}}$ \\ D. Sebag ${ }^{\mathrm{b}}$
}

- $\quad$ a ISTO, UMR CNRS 6113, Université d'Orléans, Bâtiment Géosciences, BP 6759, 45067 Orléans Cedex 02, France

- $\quad{ }^{\mathrm{b}}$ UMR CNRS 6143, Morphodynamique Continentale et Côtière, Département de Géologie, Université de Rouen, 76821 Mont Saint Aignan Cedex, France

\begin{abstract}
Application of Rock-Eval pyrolysis to soil organic matter (SOM) quantitation and characterization has been explored by the study of about 100 soil samples taken from a variety of soil profiles from different ecosystems at different latitudes. A straightforward illustration of these possibilities can be obtained from a Hydrogen Index (HI in mg hydrocarbons $\mathrm{g}^{-1}$ TOC) vs. Total Organic Carbon (TOC) diagram that effectively allows one to follow simultaneously the main qualitative (SOM hydrogen richness given by HI values) and quantitative (TOC) changes that affect SOM with increasing depth and humification, in the soil profiles. In addition, abnormally high Oxygen Index (OI in mg CO, $\mathrm{CO}_{2}$ or $\mathrm{O}_{2} \mathrm{~g}^{-1} \mathrm{TOC}$ ) values are fully diagnostic of extensive SOM alteration, as frequently observed in podzol B horizons. More detailed information on the heterogeneity of SOM and on its degree of evolution, can be gained from the shape of the pyrolysis S2 peak recorded in the course of programmed pyrolysis in an inert atmosphere $\left(\mathrm{N}_{2}\right)$ and/or from its maximum temperature " $T_{\text {peak }}$ ". All these parameters and others, all determined rapidly and automatically, are particularly useful to screen major SOM variations within large sets of samples.
\end{abstract}

\section{Introduction}

Interest in the quantitative and qualitative analysis of soil organic matter (SOM) has been motivated by its effective role in evaluating the chemical, biological and physical properties of soils (e.g. van Cleve \& Powers, 1995, Karlen et al., 1997, Robert, 1996 and Balesdent, 1996). Another interest has been provided by uncertainties on the effective role of source or sink that soils can effectively play in the global carbon cycle, with for example consequences on the greenhouse effect and climate change (Eswaran et al., 1993, Batjes, 1996, Adams \& Faure, 1996 and Carter et al., 1997). For these two reasons, and because of considerable spatial variations in the amount and composition of SOM, there is a need for techniques allowing for its fast and easy quantitation and characterisation. Rock-Eval pyrolysis allows 
one to determine the total organic carbon content (TOC wt.\%) of rocks and sediments (Espitalite et al., 1977, Espitalite et al., 1985a, Espitalite et al., 1985b and Peters, 1986). The same applies to soil samples (this paper) without the decarbonation required for classical combustion techniques. It also provides information on the composition of the OM, especially through the Hydrogen and Oxygen Index values (HI and OI) much used with other natural organic materials, e.g. kerogens, and known to correlate with $\mathrm{H} / \mathrm{C}$ and $\mathrm{O} / \mathrm{C}$ ratios (Espitalié et al., 1985b). Rock-Eval pyrolysis thus provides valuable information on the elemental composition of organic materials that is otherwise difficult to obtain because of the difficulty of isolating the OM without alteration (Stevenson, 1982 and Espitalite et al., 1977). The original goal of Rock-Eval pyrolysis was to rapidly obtain quantitative and qualitative information on the amounts of hydrocarbons and the type of kerogen present in sedimentary rocks, on the degree of thermal maturity of the kerogen and, if possible, on its approximate composition equivalent to that determined by elemental analysis. However, because of the simplicity of this technique it has been used for the analysis of soils and immature sediments (e.g. Disnar \& Trichet, 1984, Sifeddine et al., 1995, Ariztegui et al., 1996, Buillit et al., 1997, Di-Giovanni et al., 1998, Di-Giovanni et al., 1999 and Disnar et al., 2000). Here we present results of an analytical survey covering a variety of soils resulting from different soil formation processes, in different continents and with different climates.

\section{Materials and methods}

\subsection{Apparatus}

Analyses were carried out with a "Turbo" model RE6 pyrolyzer (Vinci Technologies). The basic operating principles of this apparatus are presented in Fig. 1 and described in Lafargue et al. (1998). Contrary to previous Rock-Eval devices (RE2, RE3) which only measured $\mathrm{CO}_{2}$, the measurement of $\mathrm{CO}$ by RE6 allows one to determine three 'OI's', one for $\mathrm{CO}_{2}$, one for $\mathrm{CO}$ and an additional one for $\mathrm{CO}_{2}+\mathrm{CO}$. This latter parameter called OIRE6, is expressed in $\mathrm{mg} \mathrm{O}_{2}$ $\mathrm{g}^{-1}$ TOC. 


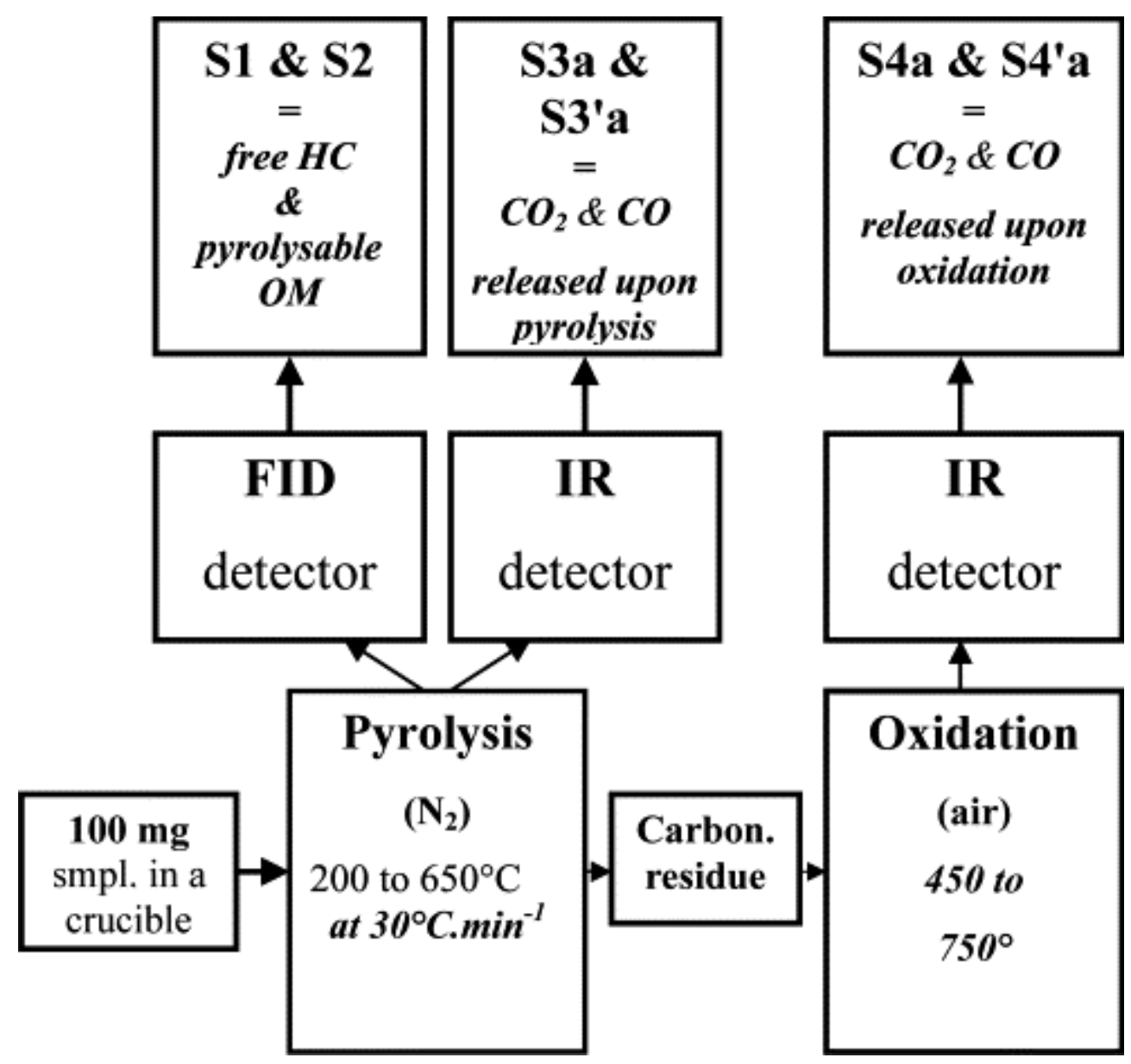

Fig. 1. Operating principles of the Rock-Eval 6 pyrolyzer (RE6)

\subsection{Sampling}

About 100 samples were collected from 24 different soil profiles of various types. These soils are tabulated (Table 1) according to their occurrence within the main world climate zones. They are named in accordance with the World Reference Base for Soil Resources (FAO, 1994). All soils are acid except chernozems (Ch 75, Ch 79) and phaeozem (Ph 81) which are neutral or basic with calcium-carbonate concretions in the deepest horizons (cf. Ahk in Ch 79). Humus and A horizon samples were collected at less than $35 \mathrm{~cm}$ depth from the surface, whereas Bh of podzols and Bt of luvic chenozems were sampled at greater depths. 
Table 1. Main characteristics and analytical data on the soil samples studied

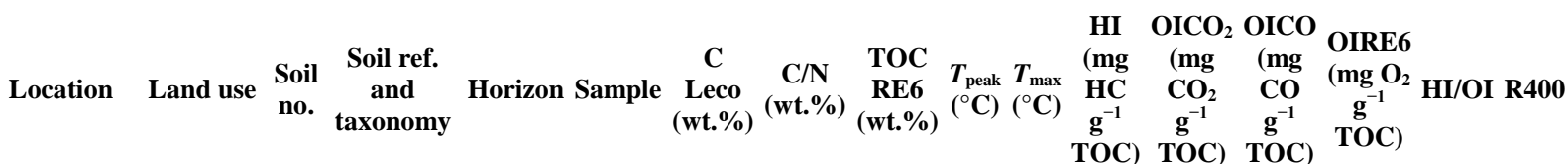

Temperate

\begin{tabular}{|c|c|c|c|c|c|c|c|c|c|c|c|c|c|c|c|c|c|}
\hline \multirow{9}{*}{$\begin{array}{l}\text { zone under } \\
\text { boreal } \\
\text { influence }\end{array}$} & $\begin{array}{l}\text { Canada } \\
\text { Victoriaville }\end{array}$ & $\begin{array}{l}\text { Pine and } \\
\text { birch } \\
\text { forest }\end{array}$ & 1 & Po 39 & $\mathrm{OL}$ & 391 & 44.4 & 38.2 & 39.21 & 359 & 319 & 381 & 224 & 70 & 203 & 1.88 & 0.70 \\
\hline & & & & $\begin{array}{l}\text { Humic } \\
\text { podzol }\end{array}$ & $\mathrm{OF}$ & 392 & 40.9 & 19.2 & 36.63 & 371 & 331 & 368 & 207 & 61 & 185 & 1.99 & 0.63 \\
\hline & & & & & $\mathrm{OH}$ & 393 & 32.7 & 14.5 & 31.44 & 370 & 330 & 342 & 206 & 64 & 186 & 1.83 & 0.47 \\
\hline & & & & & A1 & 394 & 26.7 & 18.9 & 25.03 & 426 & 386 & 338 & 178 & 57 & 162 & 2.09 & 0.48 \\
\hline & & & & & B21h & 124 & 4.5 & 26.6 & 5.59 & 467 & 427 & 84 & 430 & 109 & 375 & 0.22 & 0.33 \\
\hline & & & & & $\mathrm{B} 22 \mathrm{~h}$ & 125 & 1.9 & 21.1 & 1.98 & 457 & 417 & 91 & 466 & 120 & 408 & 0.22 & 0.25 \\
\hline & & & & & Bfe & 126 & & & & & & & & & & & \\
\hline & $\begin{array}{l}\text { Canada } \\
\text { Victoriaville }\end{array}$ & Pine forest & 2 & Po 13 & B21h & 137 & 2.2 & 31.8 & 2.37 & 469 & 429 & 47 & 308 & 106 & 284 & 0.17 & 0.27 \\
\hline & & & & $\begin{array}{l}\text { Duric } \\
\text { podzol }\end{array}$ & B22h & 138 & 1.8 & 28.4 & 1.92 & 470 & 430 & 39 & 312 & 107 & 288 & 0.14 & 0.25 \\
\hline
\end{tabular}

Temperate

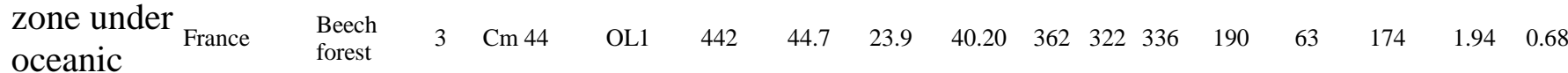
influence

\begin{tabular}{|c|c|c|c|c|c|c|c|c|c|c|c|c|c|c|c|c|c|}
\hline & Brittany & & & $\begin{array}{l}\text { Distric } \\
\text { cambisol }\end{array}$ & OL2 & 443 & 40.3 & 15.6 & 35.74 & 363 & 323 & 373 & 272 & 60 & 232 & 1.61 & 0.65 \\
\hline & Fougères & & & & $\mathrm{OF}$ & 444 & 44.1 & 21.3 & 40.57 & 375 & 335 & 336 & 184 & 50 & 163 & 2.06 & 0.55 \\
\hline \multirow{19}{*}{$\begin{array}{l}\text { Lowland } \\
\text { areas }\end{array}$} & & & & & $\mathrm{OH} 1$ & 445 & 43.9 & 21.4 & 41.19 & 421 & 381 & 299 & 193 & 47 & 168 & 1.78 & 0.54 \\
\hline & & & & & $\mathrm{OH} 2$ & 446 & 29.6 & 19.5 & 28.01 & 430 & 390 & 311 & 186 & 57 & 167 & 1.86 & 0.49 \\
\hline & & & & & A1 & 447 & 6.4 & 20.7 & 6.22 & 466 & 426 & 387 & 173 & 41 & 150 & 2.59 & 0.47 \\
\hline & France & $\begin{array}{l}\text { Oak and } \\
\text { holly } \\
\text { forest }\end{array}$ & 4 & $\mathrm{Al} 48$ & OL1 & 482 & $47.7^{\underline{a}}$ & n.d. & 40.76 & 376 & 336 & 630 & 219 & 60 & 193 & 3.26 & 0.62 \\
\hline & Loire valley & & & Albeluvisol & OL2 & 483 & 45.2 & 37.5 & 40.39 & 378 & 338 & 420 & 198 & 65 & 181 & 2.32 & 0.66 \\
\hline & Chambord & & & & $\mathrm{OF}$ & 484 & 41.9 & 24.5 & 38.46 & 422 & 382 & 345 & 184 & 48 & 161 & 2.14 & 0.58 \\
\hline & & & & & $\mathrm{OH}$ & 485 & 20.9 & 24.3 & 19.61 & 423 & 383 & 314 & 174 & 51 & 156 & 2.01 & 0.55 \\
\hline & & & & & $\mathrm{A} 1$ & 486 & 3.9 & 21.1 & 3.85 & 431 & 391 & 350 & 168 & 55 & 153 & 2.28 & 0.55 \\
\hline & France & $\begin{array}{l}\text { Oak and } \\
\text { spruce } \\
\text { forest }\end{array}$ & 5 & $\mathrm{Al} 47$ & OL-OF & 471 & 39.1 & 21.8 & 35.34 & 421 & 381 & 333 & 179 & 53 & 161 & 2.07 & 0.55 \\
\hline & Perche & & & Albeluvisol & $\mathrm{OH}$ & 472 & 29.4 & 23.0 & 27.03 & 425 & 385 & 340 & 182 & 58 & 165 & 2.06 & 0.52 \\
\hline & Freteval & & & & A1 & 473 & 10.5 & 21.0 & 9.93 & 463 & 423 & 452 & 157 & 58 & 147 & 3.07 & 0.47 \\
\hline & France & $\begin{array}{l}\text { Oak and } \\
\text { hornbeam } \\
\text { forest }\end{array}$ & 6 & Lu 91 & $\mathrm{OF}$ & 913 & 38.1 & 20.1 & 34.30 & 379 & 339 & 379 & 202 & 63 & 183 & 2.07 & 0.60 \\
\hline & Gâtinais & & & $\begin{array}{l}\text { Typic } \\
\text { luvisol }\end{array}$ & $\mathrm{OH}$ & 914 & 25.7 & 16.9 & 24.11 & 377 & 337 & 373 & 206 & 58 & 183 & 2.04 & 0.55 \\
\hline & Montargis & & & & A11 & 915 & 3.4 & 15.3 & 3.29 & 466 & 426 & 315 & 201 & 68 & 185 & 1.70 & 0.41 \\
\hline & & & & & A12 & 916 & 2.0 & 15.8 & 1.98 & 457 & 417 & 330 & 194 & 64 & 177 & 1.86 & 0.55 \\
\hline & France & Cultivated & 7 & Lu 71 & Ap & 711 & 2.2 & 13.6 & 2.13 & 465 & 425 & 256 & 248 & 62 & 216 & 1.18 & 0.37 \\
\hline & Gâtinais & & & $\begin{array}{l}\text { Albic } \\
\text { luvisol }\end{array}$ & A12 & 712 & 0.9 & 8.3 & 0.92 & 455 & 415 & 217 & 263 & 75 & 234 & 0.93 & 0.31 \\
\hline & Montargis & & & & $\mathrm{E}$ & 713 & 0.5 & 7.3 & 0.50 & 431 & 391 & 117 & 382 & 81 & 324 & 0.36 & 0.35 \\
\hline & France & Pine forest & 8 & Po 91 & $\mathrm{OH}$ & 911 & 39.7 & 26.6 & 36.14 & 424 & 384 & 365 & 169 & 50 & 152 & 2.40 & 0.57 \\
\hline
\end{tabular}




\begin{tabular}{|c|c|c|c|c|c|c|c|c|c|c|c|c|c|c|c|c|}
\hline Location & Land use & $\begin{array}{c}\text { Soil } \\
\text { no. }\end{array}$ & $\begin{array}{l}\text { Soil ref. } \\
\text { and } \\
\text { taxonomy }\end{array}$ & Horizon & Sample & $\begin{array}{c}\text { C } \\
\text { Leco } \\
\text { (wt.\%) }\end{array}$ & $\underset{\text { (wt.\%) }}{\mathbf{C} / \mathbf{N}}$ & $\begin{array}{c}\text { TOC } \\
\text { RE6 } \\
\text { (wt. \%) }\end{array}$ & $\begin{array}{l}T_{\text {peak }} \\
\left({ }^{\circ} \mathbf{C}\right)\end{array}$ & $\begin{array}{l}T_{\max } \\
\left({ }^{\circ} \mathbf{C}\right)\end{array}$ & $\begin{array}{c}\text { HI } \\
(\mathbf{m g} \\
\mathbf{H C} \\
\mathbf{g}^{-1} \\
\text { TOC) }\end{array}$ & $\begin{array}{c}\mathrm{OICO}_{2} \\
(\mathbf{m g} \\
\mathbf{C O}_{2} \\
\mathbf{g}^{-1} \\
\text { TOC })\end{array}$ & $\begin{array}{c}\text { OICO } \\
(\mathbf{m g} \\
\text { CO } \\
\mathbf{g}^{-1} \\
\text { TOC) }\end{array}$ & $\begin{array}{c}\text { OIRE6 } \\
\left(\mathrm{mg} \mathrm{O}_{2}\right. \\
\mathrm{g}^{-1} \\
\text { TOC) }\end{array}$ & HI/OI & R400 \\
\hline Sologne & & & $\begin{array}{l}\text { Umbric } \\
\text { podzol } \\
\text { with } \\
\text { anthric Ah } \\
\text { horizons }\end{array}$ & A1 & 912 & 6.9 & 23.3 & 6.68 & 429 & 389 & 284 & 191 & 60 & 173 & 1.64 & 0.55 \\
\hline \multirow[t]{4}{*}{ Salbris } & & & & Ah1 & 351 & 1.3 & 13.7 & 1.40 & 472 & 432 & 221 & 150 & 56 & 141 & 1.57 & 0.95 \\
\hline & & & & Ah2 & 352 & 1.2 & 25.3 & 1.29 & 471 & 431 & 122 & 165 & 64 & 157 & 0.78 & 0.34 \\
\hline & & & & B21h & 353 & 1.8 & 33.7 & 1.85 & 463 & 423 & 57 & 241 & 80 & 221 & 0.26 & 0.32 \\
\hline & & & & B22h & 354 & 0.5 & 18.9 & 0.61 & 451 & 411 & 30 & 203 & 64 & 184 & 0.16 & 0.38 \\
\hline
\end{tabular}

Temperate

zone under oceanic

France

$\begin{array}{lll}\text { Spruce } & 9 & \mathrm{Cm} 20\end{array}$

OL 201

$44.9 \quad 35$

influence

\begin{tabular}{|c|c|c|c|c|c|c|c|c|c|c|c|c|c|c|c|c|c|}
\hline & $\begin{array}{l}\text { Massif } \\
\text { Central }\end{array}$ & & & $\begin{array}{l}\text { Folic } \\
\text { cambisol }\end{array}$ & OF & 202 & 30.3 & 17.8 & 28.19 & 376 & 336 & 372 & 193 & 61 & 175 & 2.13 & 0.55 \\
\hline & $\begin{array}{l}\text { Mont- } \\
\text { Lozère }\end{array}$ & & & & $\mathrm{OH}$ & 203 & 11.7 & 14.5 & 11.19 & 471 & 431 & 261 & 206 & 67 & 188 & 1.39 & 0.52 \\
\hline \multirow{20}{*}{$\begin{array}{l}\text { Highland } \\
\text { areas }\end{array}$} & & & & & A11 & 204 & 5.1 & 13.6 & 4.98 & 461 & 421 & 229 & 192 & 62 & 175 & 1.31 & 0.44 \\
\hline & & & & & $\mathrm{A} 1-\mathrm{Bw}$ & 207 & 4.2 & 12.6 & 4.06 & 468 & 428 & 164 & 196 & 53 & 173 & 0.95 & 0.35 \\
\hline & France & $\begin{array}{l}\text { Spruce } \\
\text { forest }\end{array}$ & 10 & $\mathrm{Cm} 53$ & $\mathrm{OF}$ & 531 & 32.4 & 21.8 & 30.24 & 424 & 384 & 338 & 182 & 61 & 167 & 2.03 & 0.53 \\
\hline & $\begin{array}{l}\text { Massif } \\
\text { Central }\end{array}$ & & & $\begin{array}{l}\text { Spodic } \\
\text { cambisol }\end{array}$ & $\mathrm{OH}$ & 532 & 22.3 & 21.6 & 20.63 & 422 & 382 & 332 & 200 & 64 & 182 & 1.82 & 0.54 \\
\hline & $\begin{array}{l}\text { Mont- } \\
\text { Lozère }\end{array}$ & & & & A11 & 533 & 3.8 & 17.2 & 3.92 & 469 & 429 & 215 & 253 & 75 & 227 & 0.95 & 0.42 \\
\hline & & & & & A12 & 534 & 4.5 & 14.2 & 4.68 & 443 & 403 & 217 & 244 & 76 & 221 & 0.99 & 0.41 \\
\hline & & & & & A13 & 535 & 3.9 & 16.8 & 3.88 & 470 & 430 & 196 & 241 & 77 & 220 & 0.89 & 0.42 \\
\hline & & & & & $\mathrm{A} 1-\mathrm{Bw}$ & 537 & 2.6 & 15.4 & 2.67 & 471 & 431 & 176 & 249 & 87 & 231 & 0.76 & 0.32 \\
\hline & France & $\begin{array}{l}\text { Beech } \\
\text { forest }\end{array}$ & 11 & Le 52 & OL-OF & 521 & 39.0 & 31.8 & 34.95 & 384 & 344 & 363 & 180 & 71 & 172 & 2.12 & 0.69 \\
\hline & $\begin{array}{l}\text { Massif } \\
\text { Central }\end{array}$ & & & $\begin{array}{l}\text { Folic } \\
\text { leptosol }\end{array}$ & $\mathrm{OH}$ & 523 & 28.4 & 19.7 & 28.48 & 422 & 382 & 317 & 200 & 67 & 184 & 1.72 & 0.55 \\
\hline & $\begin{array}{l}\text { Mont- } \\
\text { Lozère }\end{array}$ & & & & A11 & 524 & 5.7 & 20.6 & 5.89 & 470 & 430 & 188 & 236 & 77 & 216 & 0.87 & 0.39 \\
\hline & & & & & A13 & 526 & 4.6 & 21.3 & 4.64 & 472 & 432 & 177 & 245 & 81 & 224 & 0.79 & 0.30 \\
\hline & & & & & A14 & 527 & 3.6 & 20.6 & 3.59 & 470 & 430 & 198 & 258 & 84 & 236 & 0.84 & 0.29 \\
\hline & France & $\begin{array}{l}\text { Beech } \\
\text { forest }\end{array}$ & 12 & An 93 & A11 & 931 & 11.5 & 11.9 & 10.92 & 472 & 432 & 159 & 327 & 84 & 286 & 0.55 & 0.36 \\
\hline & $\begin{array}{l}\text { Massif } \\
\text { Central }\end{array}$ & & & $\begin{array}{l}\text { Mollic } \\
\text { andosol }\end{array}$ & A12 & 932 & 9.1 & 12.2 & 8.85 & 471 & 431 & 121 & 365 & 88 & 316 & 0.38 & 0.25 \\
\hline & $\begin{array}{l}\text { Puy } \\
\text { Mercoeur }\end{array}$ & & & & A13 & 933 & 8.8 & 12.5 & 8.80 & 472 & 432 & 115 & 365 & 85 & 314 & 0.37 & 0.25 \\
\hline & & & & & $\mathrm{A} 1-\mathrm{Bw}$ & 934 & 5.7 & 13.5 & 5.62 & 472 & 432 & 95 & 442 & 92 & 374 & 0.25 & 0.21 \\
\hline & France & $\begin{array}{l}\text { Beech } \\
\text { forest }\end{array}$ & 13 & An 16 & A1 & 161 & 7.0 & 14.7 & 6.82 & 470 & 430 & 156 & 295 & 87 & 264 & 0.59 & 0.33 \\
\hline & $\begin{array}{l}\text { Massif } \\
\text { Central }\end{array}$ & & & $\begin{array}{l}\text { Cambic } \\
\text { andosol }\end{array}$ & A1-Bw & 162 & n.d. & n.d. & 3.12 & 465 & 425 & 90 & 407 & 102 & 354 & 0.25 & 0.26 \\
\hline & Le Bouchet & & & & & & & & & & & & & & & & \\
\hline
\end{tabular}

Temperate

zone under continental influence 


\begin{tabular}{|c|c|c|c|c|c|c|c|c|c|c|c|c|c|c|c|c|}
\hline Location & Land use & $\begin{array}{c}\text { Soil } \\
\text { no. }\end{array}$ & $\begin{array}{l}\text { Soil ref. } \\
\text { and } \\
\text { taxonomy }\end{array}$ & Horizon & Sample & $\begin{array}{c}\text { C } \\
\text { Leco } \\
(\text { wt. \%) }\end{array}$ & $\begin{array}{c}\mathrm{C} / \mathrm{N} \\
(\mathrm{wt} . \%)\end{array}$ & $\begin{array}{c}\text { TOC } \\
\text { RE6 } \\
\text { (wt. \%) }\end{array}$ & $\begin{array}{l}T_{\text {peak }} \\
\left({ }^{\circ} \mathrm{C}\right)\end{array}$ & $\begin{array}{l}T_{\text {max }} \\
\left({ }^{\circ} \mathbf{C}\right)\end{array}$ & $\begin{array}{c}\text { HI } \\
(\mathrm{mg} \\
\text { HC } \\
\mathrm{g}^{-1} \\
\text { TOC) }\end{array}$ & $\begin{array}{c}\mathrm{OICO}_{2} \\
(\mathbf{m g} \\
\mathrm{CO}_{2} \\
\mathrm{~g}^{-1} \\
\mathrm{TOC})\end{array}$ & $\begin{array}{c}\text { OICO } \\
(\mathbf{m g} \\
\mathbf{C O} \\
\mathbf{g}^{-1} \\
\text { TOC) }\end{array}$ & $\begin{array}{c}\text { OIRE6 } \\
\text { (mg O }_{2} \\
\mathbf{g}^{-1} \\
\text { TOC) }\end{array}$ & HI/OI & R400 \\
\hline \multirow[t]{2}{*}{ Baltati } & & & $\begin{array}{l}\text { Luvic } \\
\text { chernozem }\end{array}$ & Ah2 & 752 & 2.1 & 13.3 & 1.99 & 436 & 396 & 39 & 207 & 50 & 179 & 0.22 & 0.36 \\
\hline & & & & $\mathrm{Bt}$ & 753 & 1.4 & 12.2 & 1.37 & 403 & 363 & 35 & 216 & 59 & 191 & 0.18 & 0.33 \\
\hline Bulgaria & Mixed oak & 15 & $\mathrm{Ph} 81$ & A1 & 811 & 3.5 & 10.2 & 3.45 & 453 & 413 & 164 & 235 & 77 & 214 & 0.76 & 0.40 \\
\hline \multirow[t]{2}{*}{ Gritvitsa } & forest & & $\begin{array}{l}\text { Luvic } \\
\text { phaeozem }\end{array}$ & Bt1 & 812 & 0.8 & 6.7 & 0.82 & 401 & 361 & 72 & 330 & 113 & 305 & 0.23 & 0.38 \\
\hline & & & & $\mathrm{Bt}$ & 813 & 0.6 & 5.6 & 0.54 & 402 & 362 & 59 & 438 & 130 & 393 & 0.15 & 0.34 \\
\hline Bulgarie & Cultivated & 16 & Ch 79 & Ah1 & 791 & 1.6 & 13.0 & 1.52 & 446 & 406 & 87 & 130 & 70 & 135 & 0.65 & 0.31 \\
\hline \multirow[t]{2}{*}{ Trastenik } & & & $\begin{array}{l}\text { Calcic } \\
\text { chernozem }\end{array}$ & $\mathrm{Ah} 2 \mathrm{k}$ & 792 & 1.2 & 15.1 & 1.26 & 467 & 427 & 116 & 319 & 69 & 271 & 0.43 & 0.26 \\
\hline & & & & Ah3k & 793 & 1.0 & 19.5 & 0.86 & 450 & 410 & 87 & 403 & 78 & 338 & 0.26 & 0.31 \\
\hline Colombia & Grassland & 17 & $\mathrm{Fe} 86$ & Ah1 & 861 & 2.4 & 9.2 & 2.27 & 465 & 425 & 179 & 254 & 69 & 224 & 0.80 & 0.40 \\
\hline Bogota & & & $\begin{array}{l}\text { Eutric } \\
\text { ferralsol }\end{array}$ & & & & & 0.00 & & & & & & & & \\
\hline \multicolumn{17}{|l|}{ Sapo } \\
\hline Colombia & Grassland & 18 & $\mathrm{Fe} 85$ & Ah1 & 851 & 3.4 & 15.3 & 3.21 & 513 & 473 & 51 & 346 & 87 & 302 & 0.17 & 0.16 \\
\hline Bogota & & & $\begin{array}{l}\text { Eutric } \\
\text { ferralsol }\end{array}$ & Ah2 & 852 & 3.5 & 22.1 & 3.69 & 473 & 433 & 63 & 266 & 71 & 234 & 0.27 & n.d. \\
\hline \multicolumn{17}{|l|}{ Suesca } \\
\hline Cameroun & Savanna & 19 & $\mathrm{Fe} 89$ & OL-OF & 891 & $41.7^{\mathrm{a}}$ & 48.1 & 35.60 & 347 & 307 & 409 & 263 & 104 & 251 & 1.63 & 0.80 \\
\hline Bertoua & & & $\begin{array}{l}\text { Dysric } \\
\text { ferralsol }\end{array}$ & A11 & 892 & 2.7 & 12.3 & 2.70 & 454 & 414 & 91 & 220 & 80 & 206 & 0.44 & 0.39 \\
\hline Kandara & & & & A12 & 893 & 1.3 & 9.2 & 1.21 & 445 & 405 & 105 & 341 & 125 & 319 & 0.33 & 0.36 \\
\hline Cameroun & $\begin{array}{l}\text { Semi- } \\
\text { deciduous } \\
\text { forest }\end{array}$ & 20 & $\mathrm{Fe} 90$ & OL-OF & 901 & $43.6^{\mathrm{a}}$ & 20.7 & 37.57 & 353 & 313 & 410 & 268 & 75 & 238 & 1.73 & 0.75 \\
\hline Bertoua & & & $\begin{array}{l}\text { Dystric } \\
\text { ferrasol }\end{array}$ & $\mathrm{OH}$ & 902 & 34.5 & 12.7 & 31.56 & 372 & 332 & 335 & 230 & 65 & 204 & 1.64 & 0.61 \\
\hline \multirow[t]{2}{*}{ Kandara } & & & & A11 & 903 & 5.0 & 11.3 & 4.79 & 456 & 416 & 175 & 230 & 69 & 207 & 0.85 & 0.39 \\
\hline & & & & A12 & 904 & 1.8 & 8.9 & 1.73 & 443 & 403 & 105 & 291 & 81 & 258 & 0.41 & 0.36 \\
\hline Congo & Savanna & 21 & $\operatorname{Ar} 87$ & OL & 871 & 5.8 & 17.3 & 5.46 & 324 & 284 & 335 & 152 & 74 & 153 & 2.19 & 0.63 \\
\hline \multirow[t]{3}{*}{$\begin{array}{l}\text { Pointe } \\
\text { Noire }\end{array}$} & & & $\begin{array}{l}\text { Ferralic } \\
\text { arenosol }\end{array}$ & A11 & 872 & 0.7 & 7.2 & 0.69 & 453 & 413 & 173 & 219 & 66 & 197 & 0.88 & 0.54 \\
\hline & & & & A12 & 873 & 0.6 & 8.1 & 0.60 & 456 & 416 & 144 & 239 & 68 & 212 & 0.68 & 0.42 \\
\hline & & & & A13 & 874 & 0.4 & 6.7 & 0.47 & 456 & 416 & 182 & 259 & 70 & 229 & 0.80 & 0.45 \\
\hline Congo & $\begin{array}{l}\text { Eucalyptus } \\
\text { plantation }\end{array}$ & 22 & $\operatorname{Ar} 88$ & OL & 881 & $51.3^{\mathrm{a}}$ & 71.5 & 44.21 & 371 & 331 & 482 & 156 & 45 & 139 & 3.46 & 0.65 \\
\hline \multirow[t]{3}{*}{$\begin{array}{l}\text { Pointe } \\
\text { Noire }\end{array}$} & & & $\begin{array}{l}\text { Ferralic } \\
\text { arenosol }\end{array}$ & A11 & 882 & 1.0 & 9.9 & 0.93 & 452 & 412 & 186 & 240 & 71 & 215 & 0.86 & 0.43 \\
\hline & & & & A12 & 883 & 0.5 & 5.7 & 0.40 & 450 & 410 & 93 & 306 & 63 & 258 & 0.36 & 0.39 \\
\hline & & & & A13 & 884 & 0.4 & 4.4 & 0.32 & 447 & 407 & 90 & 321 & 68 & 273 & 0.33 & 0.41 \\
\hline Congo & Savanna & 23 & Po 83 & A11 & 831 & 1.3 & 17.0 & 1.26 & 471 & 431 & 452 & 139 & 46 & 127 & 3.55 & 0.39 \\
\hline \multirow[t]{3}{*}{$\begin{array}{l}\text { Pointe } \\
\text { Noire }\end{array}$} & & & $\begin{array}{l}\text { Duric } \\
\text { podzol }\end{array}$ & A12 & 832 & 0.3 & 4.9 & 0.29 & 327 & 287 & 227 & 192 & 65 & 177 & 1.28 & 0.57 \\
\hline & & & & B21h & 833 & 1.1 & 16.6 & 1.20 & 459 & 419 & 64 & 152 & 45 & 137 & 0.47 & 0.36 \\
\hline & & & & B22h & 834 & 2.0 & 36.6 & 2.09 & 445 & 405 & 36 & 166 & 77 & 164 & 0.22 & 0.35 \\
\hline Congo & Savanna & 24 & Po 14 & B21h & 141 & 5.2 & 49.9 & 6.28 & 455 & 415 & 35 & 166 & 98 & 177 & 0.20 & 0.26 \\
\hline Brazzaville & & & $\begin{array}{l}\text { Humic } \\
\text { podzol }\end{array}$ & B22h & 142 & 2.5 & 22.5 & 2.25 & 470 & 4 & & & & & & \\
\hline
\end{tabular}


n.d.=Not determined.

a C (wt.\%) value of litter sample rather strongly underestimated by RE6 pyrolysis.

The cold and humid climate of the boreal Canadian zone is favourable for podzol development on glacial till or crystalline bedrock poor in clay and weathered minerals. Forest soils present humus of moder or mor type including a thick $\mathrm{OH}$ horizon rich in faecal pellets, overlying an A1 horizon comprising organic aggregates juxtaposed to quartz grains. Spodic $\mathrm{B} 21 \mathrm{~h}$ and $\mathrm{B} 22 \mathrm{~h}$ horizons result from the accumulation of organic-Fe-Al complexes translocated through eluvial horizons from the humus layers. In such spodic horizons, organic matter forms either grain coatings causing a strong skeleton grain cementation (Po 13) or aggregates originating from root decay (cf. samples nos. 124 and 125 in Po 39).

In lowland areas of the temperate zone (Table 1), soils developed on loamy materials are frequently cultivated. We sampled only one of them ( $\mathrm{Lu} \mathrm{71)}$ in the vicinity of a forest profile (Lu 91) from which it derives by clearfelling and cultivation. We also collected topsoil profiles in deciduous forests of beech (Fagus silvatica, cf. Cm 44), of oak (Quercus sessiliflora) somewhere mixed with indigenous holly (Ilex aquifolium, $\mathrm{cf}$. $\mathrm{Al} 48$ ) or with planted conifers such as spruce (Picea abies, cf. Al 47). Humus were moder from which we separated OL, OF and OH horizons, especially in oak and beech forests. The thickness of the $\mathrm{OH}$ horizon varied from 0.5 to $2 \mathrm{~cm}$.

Whereas boreal zone podzolization is a climatic process, in temperate and even tropical climate zones, podzols might have developed provided that parent materials were poor in alterable minerals. Thus, umbric podzols (Po 91) have developed on Tertiary sands, under Pinus sp, in Sologne (Fr). Such soils have developed thick humus as well as anthric Ah horizons and Bh, during a past heathland phase.

Soil profiles of highland areas of the temperate zone were collected under forests in the Massif Central (France). Cambisols (Cm 20, Cm 53) and leptosol (Le 52) rich in TOC, have been formed under beech or spruce on granite at Mont Lozère (1.300-1.400 m elevation) whereas andosols (An 93, An 16) have developed under beech on basalt in the "Chaine des Puys" (1.200 m elev.). Cambisols and leptosol frequently display a thick moder OH horizon with a $\mathrm{C} / \mathrm{N}$ value of about 20 which decreases slightly in the underlying A1 horizons. In contrast, andosols have a mollic epipedon corresponding to a mull type humus. In such soils the beech litter is quickly degraded, and there is incorporation of much organic matter in all horizons, even in the deepest ones.

In the temperate zones under continental influence (Table 1), chernozems (Ch 75, Ch 79) cover a large surface of Eurasian steppes in association with phaeozems ( $\mathrm{Ph} \mathrm{81)}$ which are present in most humid areas where deciduous forests were preserved. These soils are characterized by their dark brown mollic horizons, much grass root production and intense biological activity, especially of earthworms, in frequently cultivated chernozems. Despite their blackish color, these soils have low TOC contents and $\mathrm{C} / \mathrm{N}$ values.

In tropical zones, there is diversity of soil-forming processes because climates, parent materials and pedogenesis vary from one area to another. We sampled three locations in Colombia, Cameroon and Congo. Eutric ferralsols ( $\mathrm{Fe} \mathrm{85,} \mathrm{Fe} \mathrm{86}$ ) sampled in the Colombian oriental cordillera near Bogota support tall grass savannas (Guillet et al., 1988). In Cameroon, 
two dystric ferralsol profiles ( $\mathrm{Fe} 89, \mathrm{Fe} 90)$ were sampled in a tall grass savanna and in an adjacent semi-deciduous forest which encroached on the savanna less than 100 years ago (Guillet et al., 2001). Excluding litter fragments (OL-OF, OH), the top-soil A11 and A12 horizons present a sandy clay texture consisting of about $50 \%$ of clay minerals. Intense biological activity within the first $25 \mathrm{~cm}$ explains the relatively high TOC contents and low $\mathrm{C} / \mathrm{N}$ values, especially in forests. Arenosol profiles ( $\mathrm{Ar} 87$, Ar 88) collected in the Congo are typical ferralitic soils developed on sandy parent materials poor in clay. Contrasting with Cameroonian soils, there is a small accumulation of organic matter in topsoil, probably due to the insufficient adsorbing properties of kaolinite-type clay minerals. On such very poor parent materials giant podzols (Po 14, Po 83) were observed in the Congo (Schwartz, 1988). These soils present thick and indurated B21h and B22h horizons poor in organic nitrogen. Some of them presently in savanna are fossil podzols that developed in a formerly hydromorphous forest environment (Schwartz et al., 1986).

\section{Results and discussion}

\subsection{TOC (\%) determination and limitations}

One advantage of Rock-Eval pyrolysis is to provide TOC values without preliminary treatment such as decarbonatation as required for the determination of the organic carbon by classical combustion techniques. As shown in Fig. 2, there is a very good correlation $\left(R^{2}=0.998\right)$ between TOC values determined by Rock-Eval 6 and in carbonate-free samples on a Leco analyser. However, the Rock-Eval TOC values are, on average, $9.16 \%$ lower on a relative basis, than those determined by the Leco technique. This difference arises because of a lower response of the FID detector to the hydrogen-poor SOM pyrolysates than to those of the 55000 IFP marl standard. In addition, part of the SOM hydrogen is probably lost as $\mathrm{H}_{2} \mathrm{O}$, not detected by the FID, as a result of dehydration reactions. This general interpretation is substantiated by the fact that the greatest discrepancy between the two techniques is usually observed for litter samples. Such samples are rich in carbon but with notable proportions of cellulose and other polysaccharides which easily lose water on heating. Under more drastic heating these polymers decompose giving oxygenated compounds, e.g. furfurals, that produce a lower FID response than fully hydrogenated moieties. One way to solve the TOC problem is to use a more adequate standard than IFP 55 000. The other way is to keep the same standard, to avoid any confusion, but to correct the experimental data by a constant factor. After the correlation presented in Fig. 2, the experimental TOC values must be divided by 0.916 (or multiplied by 1.092). A supplementary correcting factor (1.068) should be specifically applied to biopolymer-rich samples of forest soil litter (e.g. samples 482, 881, 891, 901 in Table 1). No correction has been made in this paper. 


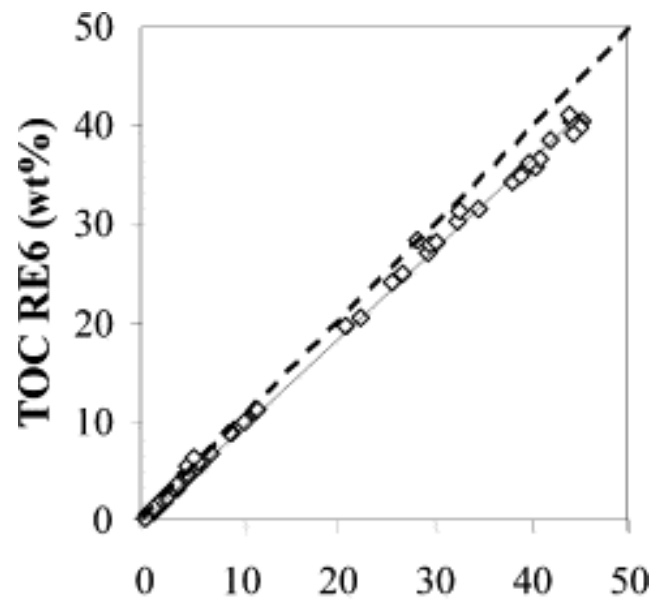

\section{Total Carbon Leco $(w t \%)$}

Fig. 2. Correlation between TOC contents (\%) determined by RE6 pyrolysis (+ oxidation) with Total carbon contents determined by classical combustion with a Leco CNS-2000 analyzer. The absence of carbonates in the samples allows for the direct comparison of Total carbon Leco determinations with RE6 TOC measurements. The samples of fresh litter nos. 482, 881, 891 and 901 (Table 1) have not been taken into account for this comparison (see text).

The data presented in Fig. 2 already allows one to appreciate the precision of the method. Replicate analyses of soil samples show excellent TOC reproducibility, with an analytical error normally lower than 2\% (Disnar et al., 2000).

The use of TOC values for characterising SOM and distinguishing soil profiles will be discussed later, together with HI and OI results.

The standard deviation on the other main parameters are: $T_{\text {peak }} \pm 5^{\circ} \mathrm{C} ; \mathrm{HI}: \pm 6 \%$; OI RE6: $\pm 10 \%$.

\subsection{Free hydrocarbonaceous compounds ( $\mathrm{S} 1$ peak)}

Except in case of contamination by low molecular weight organics, $\mathrm{S} 1$ is usually minor in soils and can thus generally be neglected.

\subsection{Hydrogen and oxygen index values ( $\mathrm{HI}$ and $\mathrm{OI}$ )}

Previous work on kerogen has demonstrated that the Hydrogen Index and Oxygen Index values correlate with atomic $\mathrm{H} / \mathrm{C}$ and O/C values, respectively (Espitalié et al., 1977). The determination of such correlations requires one to determine the elemental composition of a large set of samples free of mineral matter. Such samples are very difficult to obtain from soils because the isolation treatment considerably alters recent organic material (Stevenson, 1982).

Before further discussing the data, two points are worth mentioning. First, analysis of TOCpoor rock samples frequently show a decrease of HI values with decreasing TOC. Thus, S2 vs. TOC plots generally show a correlation curve that intercepts the abscissa axis (Langford and Blanc-Valleron, 1990). This phenomenon may result from successive retention and dehydrogenation of increasing proportions of pyrolysis products by the mineral matrix, with 
decreasing TOC content (Espitalite et al., 1984 and Espitalite et al., 1985b). Clays and especially illite and attapulgite have the most pronounced effect whereas kaolinite is almost completely inactive (Makadi Kimpanga, 1982 and Espitalite et al., 1984). As examplified in Fig. 3, for soils, the S2 vs. TOC correlation curve that tends towards the origin of the axes indicates that there is no noticeable mineral matrix effect and thus no alteration of HI values for SOM-poor samples. This might firstly result from the absence of active mineral species in the corresponding A and B horizons, and secondly also from the low dehydrogenation capacity of the already hydrogen-poor SOM and of its pyrolysis products.

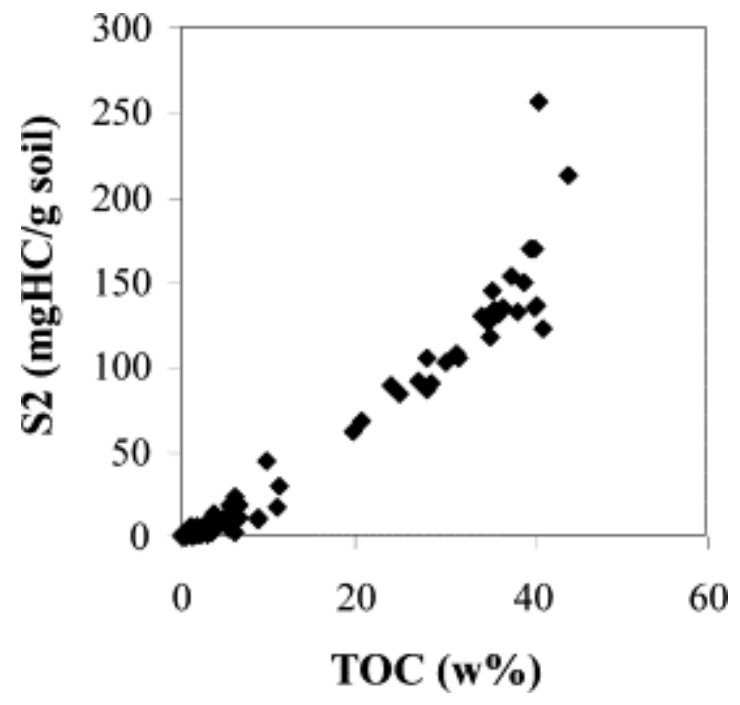

Fig. 3. Pyrolysable SOM contents ( $\mathrm{S} 2$ in $\mathrm{mg} \mathrm{HC} \mathrm{g}^{-1}$ sample) vs. TOC (\%) for the soil samples studied.

The second remark concerns the oxygen index OI, or more precisely the three different oxygen indexes that can be determined by RE6 (see Experimental). The data presented in Table 1 show that IOCO varies much less (i.e. by factor two) than $\mathrm{OICO}_{2}$ and that this latter is much greater than OICO (about 3 times as a mean). Despite the fact that OIRE6 and $\mathrm{OICO}_{2}$ are not strictly equivalent (even if $\mathrm{CO}$ is relatively minor with regard to $\mathrm{CO}_{2}$ ) and in addition, that they are not expressed in the same units ( $\mathrm{mg} \mathrm{CO}_{2} \mathrm{~g}^{-1}$ TOC vs. $\mathrm{mg} \mathrm{O}_{2} \mathrm{~g}^{-1}$ TOC) their correlation and their close numerical values allow us to use the one or the other in soil analysis (Fig. 4). 


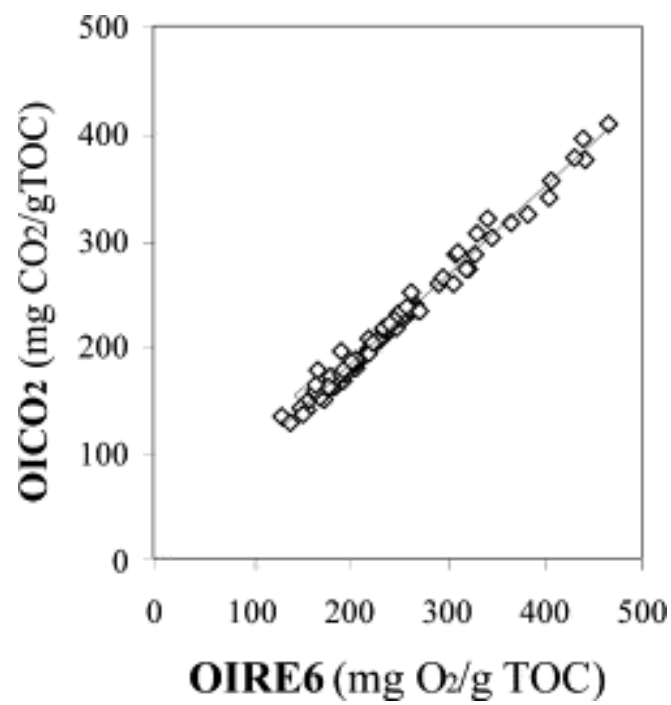

Fig. 4. Comparison between OIRE6 and OICO2 values showing the high degree of correlation between these two parameters.

When plotted in an HI vs. OI diagram, the data corresponding to the various soil horizons mostly show decreasing HI values with increasing depth in the soil profiles and thus increasing humification (Fig. 5). OI values show increasing scattering from the upper layers, down to the B horizon in which SOM only displays residual HI values of 100 or less, and variable but generally high OIRE6 values of $100-400 \mathrm{mg} \mathrm{O}_{2} \mathrm{~g}^{-1}$ TOC. The downward general evolution trend exhibited by SOM is comparable to that experienced by weathered coals (e.g. Lo and Cardott, 1995). It consists in a progressive oxidation that begins with dehydrogenation (i.e. HI decreases) and eventually goes on with a gain in oxygen (i.e. OI increases). This latter phenomenon is especially well marked in podzol B horizons where SOM has also been oxidised in the course of humification and/or as a result of humic substance illuviation (Fig. 5). The gross transformations of SOM depicted by HI and OI variations can also be compared to the $\mathrm{C} / \mathrm{N}$ ratio. As illustrated in Fig. 6, the mineralisation of polysaccharides and other N-poor biopolymers is responsible for the decrease of the $\mathrm{C} / \mathrm{N}$ ratio in the top soil layers (OL, OF), without any marked HI decrease. With large variations depending on individual sites the SOM from A horizon samples globally presents rather low $\mathrm{HI}$ and $\mathrm{C} / \mathrm{N}$ values as a result of strong alteration. In contrast, in the underlying B horizons in podzols, the SOM presents still lower $\mathrm{HI}$ and frequently higher $\mathrm{C} / \mathrm{N}$ ratio values. The latter are typical for the N-poor highly oxygenated compounds that accumulate in such horizons (e.g. Andreux et al., 1986). 


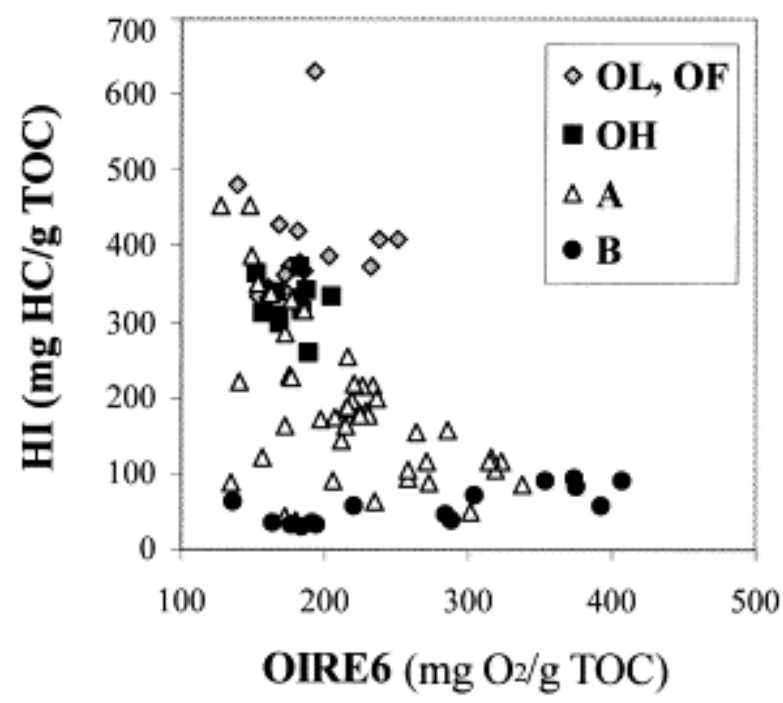

Fig. 5. HI vs. Ol diagram (comparable to the classical Van Krevelen $\mathrm{H} / \mathrm{C}$ vs. O/C diagram).

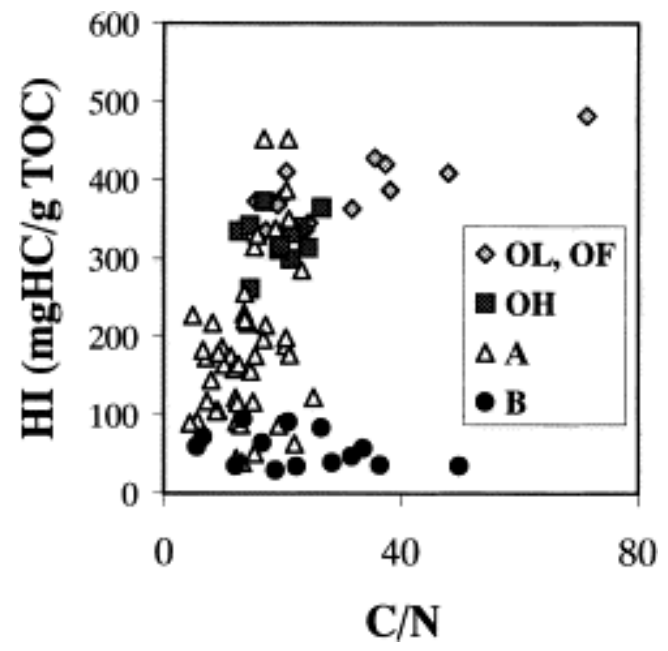

Fig. 6. HI vs. C/N diagram.

A more useful presentation than the HI vs. OI plot might be an HI vs. TOC diagram (Fig. 7). This allows one to appreciate the main variations in SOM quality given by HI values, together with those in TOC contents, mostly governed by the mineralisation of SOM and its dilution by the mineral matrix. All the samples of fresh and fragmented litter (OL and OF) normally show high TOC values (10-40\%) and $\mathrm{HI}$ values higher than $300 \mathrm{mg} \mathrm{HC} \mathrm{g}{ }^{-1}$ TOC. Such $\mathrm{HI}$ values are expected for minimally transformed terrestrial plant material rich in polysaccharides, lignin and other biopolymers. Because the transformation of the original biological inputs in the litter is small, the scattering of the corresponding data points mostly originates from the variation in composition of the parent plants. This is illustrated in Fig. 7 by a sample of litter of holly and oak which displays a very high HI value (>600 $\mathrm{mg} \mathrm{HC} \mathrm{g}^{-1} \mathrm{TOC}$ ) demonstrating the richness of the holly waxes. Generally, the $\mathrm{OH}$ soil layers display only slightly lower TOC and HI values than those of the litter. These comparable values illustrate the fact that in $\mathrm{OH}$ layers the SOM is formed of vegetal debris completely comminuted by the mesofauna, but (bio-)chemically little transformed (Zech \& Kogel-Knabner, 1994 and Disnar et al., 2001a). 


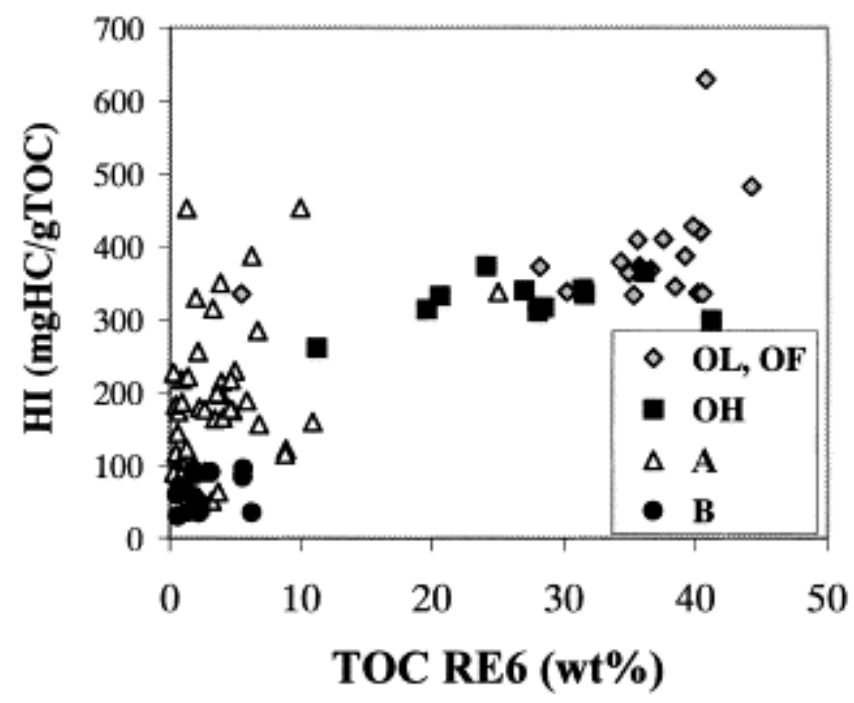

Fig. 7. HI vs. TOC diagram.

More important changes occur in the organo-mineral A horizon but with considerable variations from one soil to another as shown by HI values (Table 1) varying between 450 (e.g. soil $\mathrm{Al} \mathrm{47)}$ ) and $50 \mathrm{mg} \mathrm{HC} \mathrm{g}^{-1} \mathrm{TOC}$ (e.g. chernozem $\mathrm{Ch} 75$ and ferrasol $\mathrm{Fe} 85$ ). At the same time, TOC values vary between less than 0.5 (e.g. arenosols) and more than 10 (up to about 25 if one consider a sample of podzol-no. 394-identified as an Ah) (Table 1). This scattering results from the multiplicity of soil uses, the nature of the fine mineral fractions and uncertainties in the distinction of layers and horizons (Federer, 1982). As expected, rather high HI values are found in the top layer of the organo-mineral horizons of soil profiles due to a moder type humus where, by definition, there is no clear cut distinction between the humus layer and the underlying A1 layer (Jabiol et al., 1995). Thus, the SOM in the latter should mostly differ from that of the $\mathrm{OH}$ layer as a result of greater dilution by the mineral matrix, i.e. from a quantitative (TOC) rather than a qualitative (HI). Then, the corresponding rather high HI values mostly result from the slight transformation of the vegetal inputs due to rather low biological activity. In clay-poor soils such as sandy podzols developed under savannah high HI values are found in the A1 horizon (e.g. 452 in A11; sample 831, profile Po 83; Table 1). In A1 horizons in such sandy soils, SOM occurs as pellets formed by the active fauna. These pellets are juxtaposed but not intermingled in the mineral matrix. In most cases, SOM quantity and quality decrease with increasing depth. HI values lower that 100 are reached in the deepest layers of the A horizon and/or in the underlying spodic or cambic horizon (B). A drawback of this diagrammatic representation is that it only partly accounts for the oxidation undergone by SOM in the course of humification, i.e. the loss of hydrogen expressed by the lowering of the $\mathrm{HI}$, but not the subsequent oxygen uptake responsible for the rise of the OI. The parameter HI/OI formally related to an atomic $\mathrm{H} / \mathrm{O}$ ratio should better express the continuity of the oxidation phenomenon since it first decreases with decreasing HI, then continues to decrease with increasing OI (here taken as OI RE6). As demonstrated in Table 1, the HI/ OI ratio values of the $\mathrm{OL}, \mathrm{OF}$ and $\mathrm{OH}$ layers which contain relatively little transformed biopolymers are all equal or greater than 1.4. In contrast, samples from podzol B horizons containing highly functionalized water-soluble organics have ratios around $0.2 \pm 0.1$ (with one value approaching 0.5; Table 1) (Anderson, 1979). HI/OI values of intermediate A horizons are largely scattered between these two extremes. However high values $(>1.4)$ are found in savanna top soil, most probably due to the presence of slightly degraded plant debris (sample 831; Table 1). High HI/OI values recorded in A1 layers of soils having developed a 
mor or moder type humus are consistent with the slow SOM transformation typical of such situations (samples 473, 447, 486, 394, 916, 915, 912 and 351; Table 1).

\section{4. $T_{\max }$ and shape of the pyrolysis $S 2$ peak}

$T_{\max }$ which corresponds to the oven temperature at the maximum of the $\mathrm{S} 2$ peak is a wellknown maturity indicator ( Espitalite et al., 1985a, Espitalite et al., 1985b and Disnar, 1994). It increases regularly with increasing burial, provided that the OM has previously reached or passed the onset of the main oil generation stage $\left(T_{\max }>430-435{ }^{\circ} \mathrm{C}\right)$. Before that stage the $\mathrm{OM}$ is simply said to be immature. It is important to stress that $T_{\max }$ is about $40{ }^{\circ} \mathrm{C}$ lower than the real temperature experienced by the sample at the time it was recorded due to misplacement of the oven temperature probe in previous Rock-Eval instruments, especially in RE2 (Espitalié et al., 1985a). This problem has been corrected in Rock-Eval 6, which records the temperatures experienced by the sample. To avoid any confusion with $T_{\max }$ the corresponding true operating temperature is called " $T_{\text {peak" }}$. However, because geochemists are used to $T_{\max }$-based temperatures, the Rock-Eval 6 also accordingly "corrects" pyrolysis temperature to provide the older values. However, since $T_{\max }$ has no particular meaning for soil scientists we prefer $T_{\text {peak }}$ values which have a straightforward significance and allow a more direct comparison with pyrolysis temperatures in other instruments (e.g. Schnitzer et al., 1994 and Jocter-Montrozier \& Robin, 1988).

In immature samples the S2 peak is frequently non-gaussian and can be accompanied with shoulders. The $T_{\max } / T_{\text {peak }}$ value given the Rock-Eval corresponds to the highest peak. Previous work on recent OM has demonstrated that these various peaks or shoulders correspond to the successive cracking of organic components of different thermal stabilities (e.g. glucides before polypeptides) ( Disnar, 1982 and Disnar \& Trichet, 1984). This interpretation is here fully consistent with the very low $T_{\text {peak }}$ values of 320 to $390{ }^{\circ} \mathrm{C}$ found in the upper layers of the soils studied, i.e. OL, OF and some of the OH layers (Fig. 8). These low values are typical for the thermal breakdown of biological constituents such as polysaccharides and lignin (Fig. 9) and thus reflect the predominance of original compounds in the topsoil layers. In contrast, the $T_{\text {peak }}$ of 420 to $470{ }^{\circ} \mathrm{C}$ observed in the A and B horizons (Fig. 8) are typical of immature humic substances. As shown in Fig. 10 this distinction is well evidenced by the results of the mathematical deconvolution of S2 peaks from a few soil profiles. A detailed interpretation of the results of such a treatment is rather difficult because of the variability of biological sources and soil environments. The first peak or shoulder is at a $T_{\text {peak }}$ of 300 to $320{ }^{\circ} \mathrm{C}$. It is seldom dominant and is caused by thermally labile biological compounds ( Bigois et al., 1986 and Jocter-Montrozier \& Robin, 1988). The $T_{\text {peak }}$ at $360-370{ }^{\circ} \mathrm{C}$, frequently observed in litter (OL and OF; Fig. 8) samples, is mostly attributed to cellulose and/or lignin, two major components of woody tissues (Fig. 9), or even to other biopolymers such as polypeptides (Disnar and Trichet, 1984). The pyrolysis of these biological compounds is virtually achieved at $400{ }^{\circ} \mathrm{C}\left(360{ }^{\circ} \mathrm{C} T_{\max }\right.$-equivalent temperature $)$ while humic substances decompose at $T_{\text {peak }}$ values of about $420{ }^{\circ} \mathrm{C}$ and/or 440 to $470{ }^{\circ} \mathrm{C}$ as observed in most $\mathrm{OH}$ layers and all A and B horizons ( Fig 8 and Fig. 10). In consequence, the proportion of the S2 peak integrated before $400^{\circ}$ ( $T_{\text {peak }}$ equivalent temperature) referred to as parameter R400 in Table 1 (which should mostly depend on the proportions of biomolecules) should decrease with depth in soil profiles. This is shown by the general decrease of R400 values with depth, as in the soil profiles studied (Table 1). A further confirmation of this is given by the correlation between HI/OI and R400 values (Fig. 11). The roughly parallel change of these parameters expresses the simultaneous change of the elemental composition of the SOM structure, through the formation of humic-like substances from biopolymers. Accordingly, 
both these parameters display high values in the OL and OF topsoil layers which mostly contains hydrogen-rich biomolecules. They both change markedly in A horizons especially around HI/OI values of 1.4 and R400 values of 0.5 , respectively. This latter value might thus be taken to indicate a major stage in the transformation of SOM.

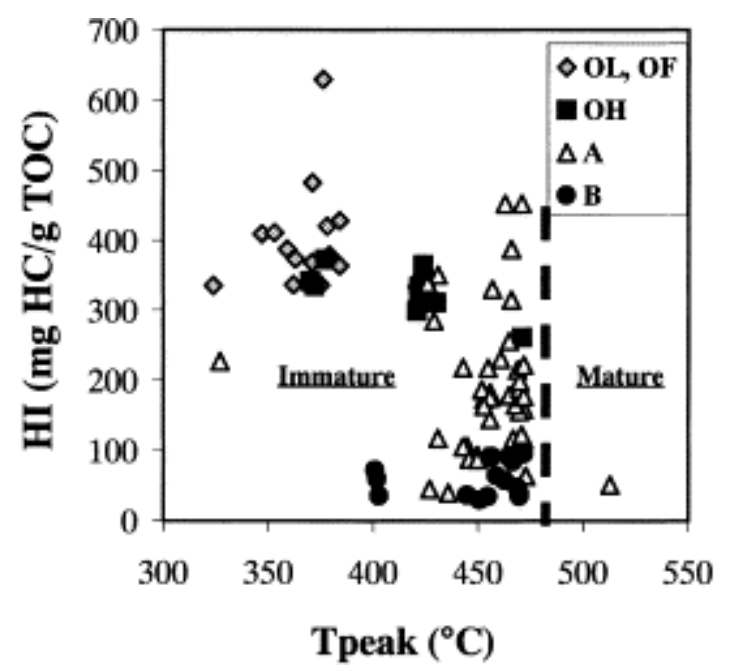

Fig 8. HI vs. $T_{\text {peak }}$ diagram. $T_{\text {peak }}$ is the accurate temperature experienced by the sample when producing the maximum amount of hydrocarbons (S2 peak) during pyrolysis in a RE6 instrument. The more classical $T_{\max }$ values obtained from previous Rock-Eval models are $40{ }^{\circ} \mathrm{C}$ lower than $T_{\text {peak }}$ temperatures (see text).

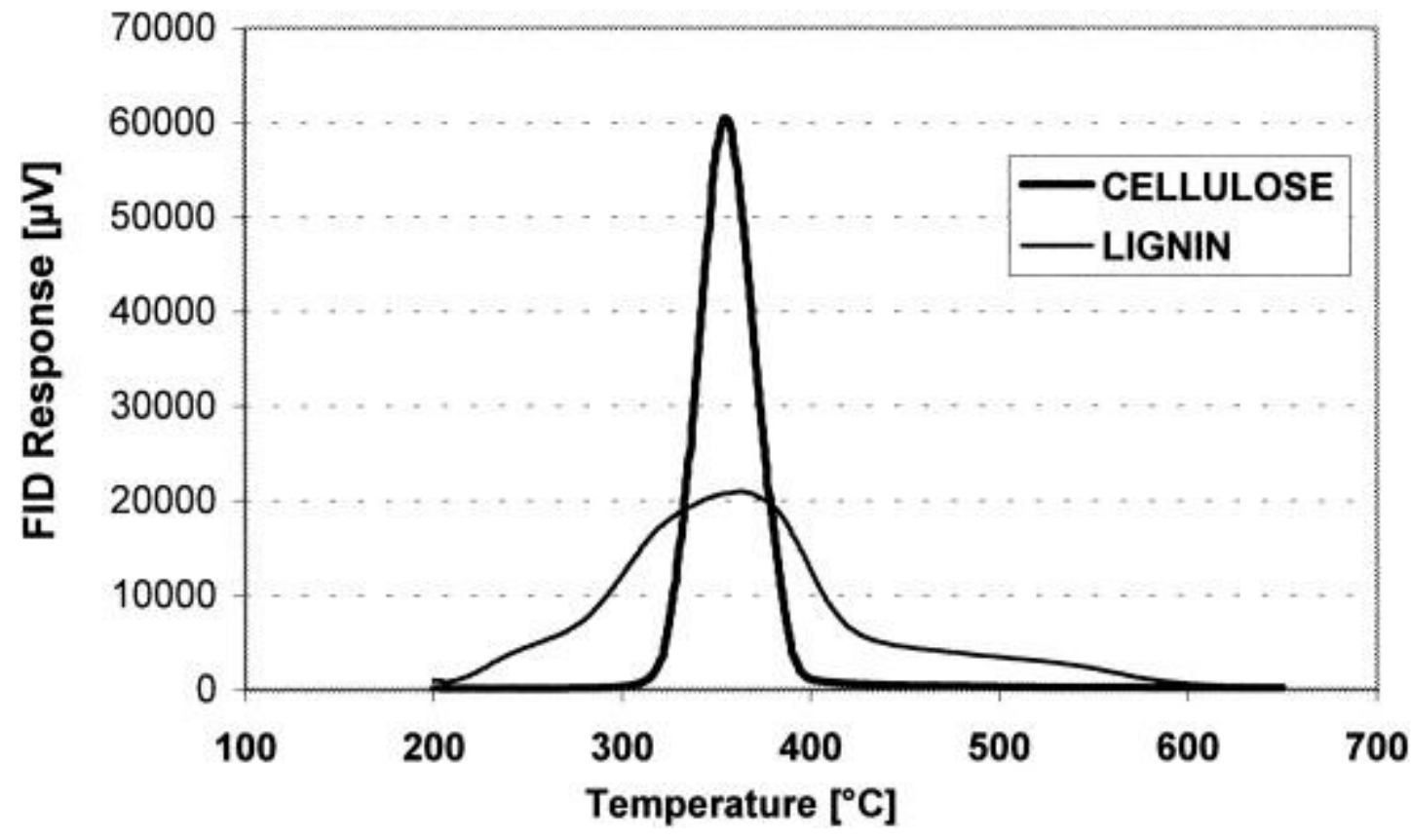

Fig. 9. Pyrograms (S2 signals) of pure cellulose and lignin. 

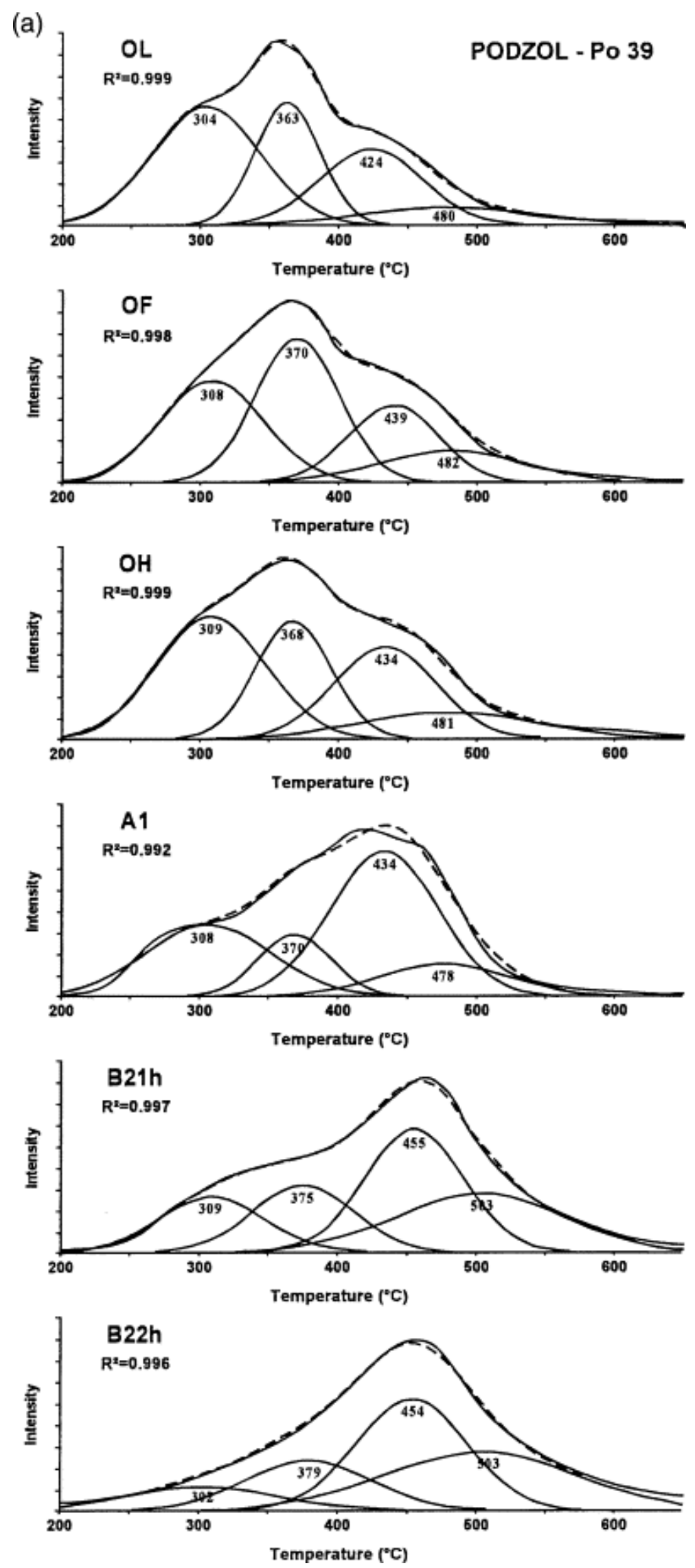

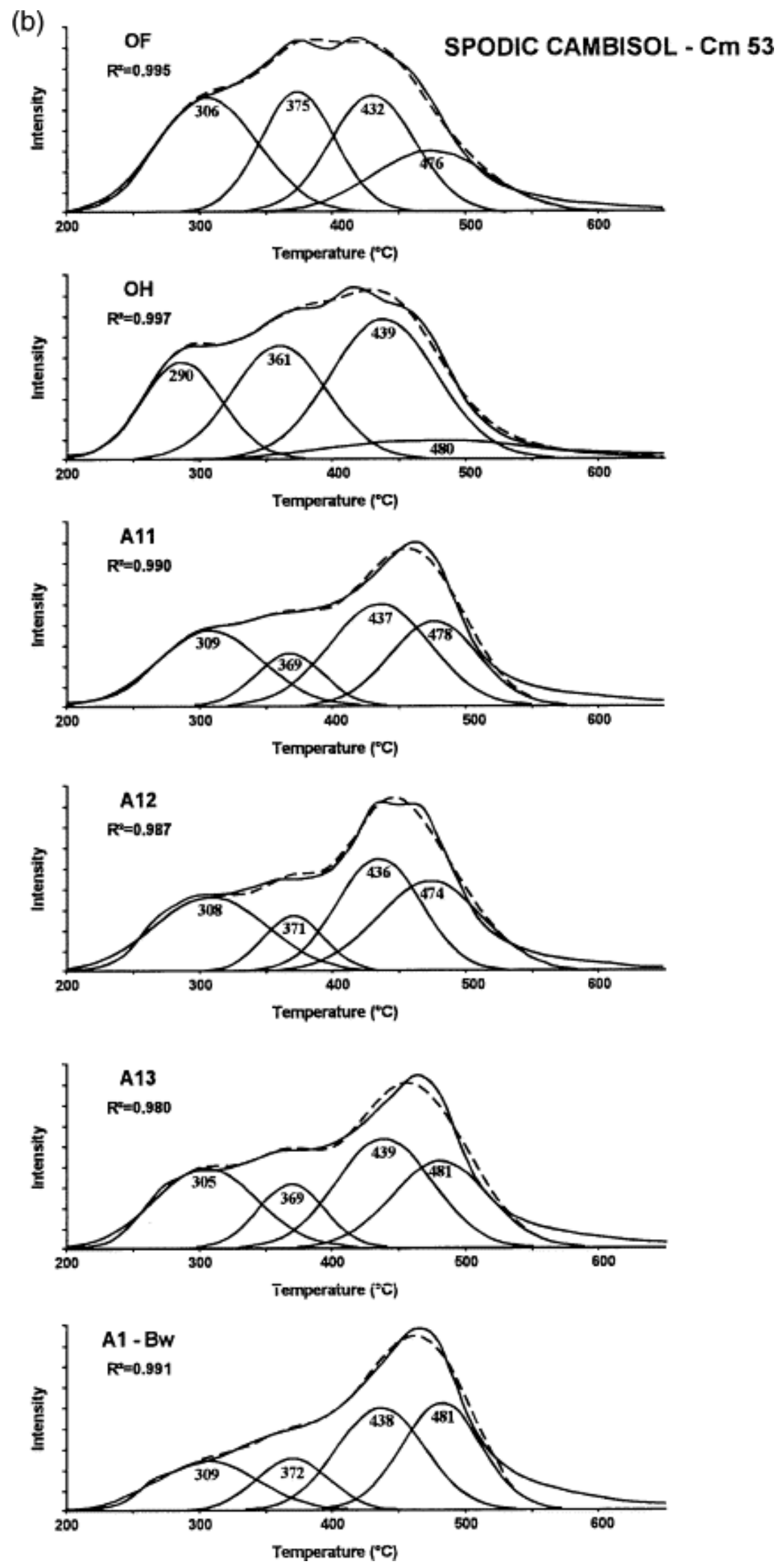

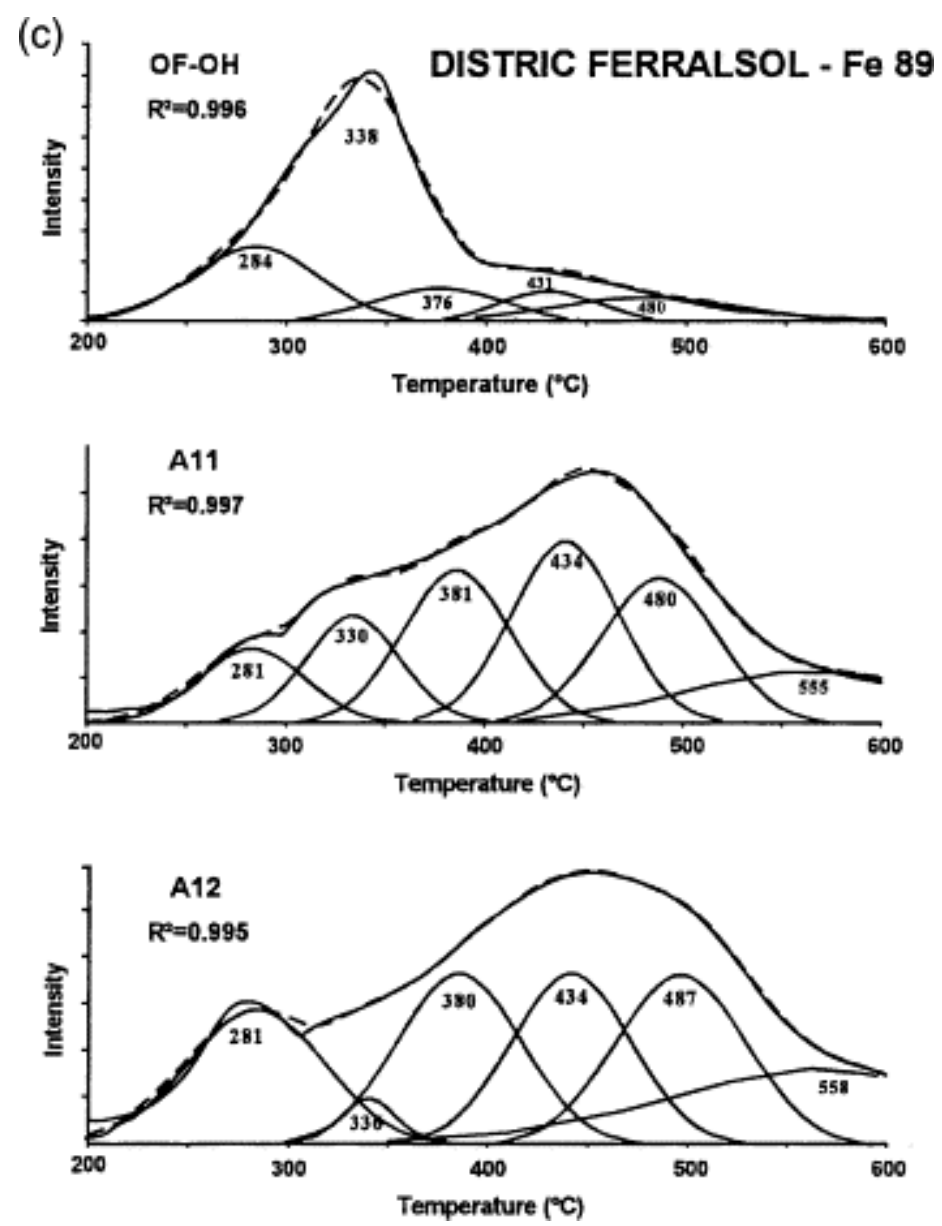

Fig. 10. Examples of pyrograms of soil samples from some of the studied profiles, with deconvolution of the multilobed S2 signals: 10a: podzol Po 39; 10b: spodic cambisol Cm 53; 10c: distric ferralsol Fe 89.

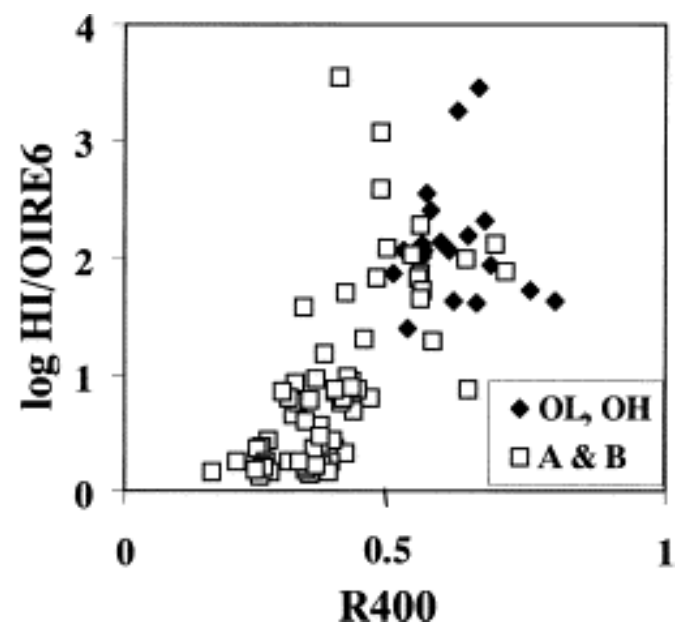

Fig. 11. R400 vs. log HI/OI diagram. R400 represents the proportion of the S2 signal integrated before $400{ }^{\circ} \mathrm{C}$ ( $T_{\text {peak }}$ equivalent pyrolysis temperature).

$T_{\max }$ values higher than $435^{\circ} \mathrm{C}$ (i.e. $T_{\text {peak }}>475^{\circ} \mathrm{C}$ ), which are sometimes observed in soils developed on sedimentary formations, and especially in the deepest horizons, are normally 
caused by mature OM reworked from the substratum ( Di-Giovanni et al., 1998, Di-Giovanni et al., 1999 and Di-Giovanni et al., 2000). Previous studies on coals and coaly materials provided evidence that the $T_{\max }$ values of such materials do not change in the course of weathering or only in the very latest stages when HI values were very low (Lo and Cardott, 1995). However, recent work shows that the invariance of $T_{\max }$ with increasing weathering only holds for weakly mature and mature materials, a marked Tmax increase with increasing alteration being observed for highly mature coals (starting equivalent vitrinite reflectance $>1.5 \%$ : Disnar et al., 2001b and Copard et al., 2002). High $T_{\text {peak }}$ values in SOM might also be caused by the presence of charcoals which have recently been judged responsible for Tpeak values of $500-600{ }^{\circ} \mathrm{C}$ found at about $1 \mathrm{~m}$ depth in laterite profiles in Brazil (Bodineau et al., 2002). The presence of such mature material admixed with variable amounts of recent organics, might also be responsible for the $T_{\text {peak }}$ value of $513{ }^{\circ} \mathrm{C}$ given by the topsoil of a Columbian ferralsol. (sample 851; Table 1).

\section{Conclusions}

Rock-Eval pyrolysis rapidly provides essential information on the amount and composition of SOM. In addition to information on the abundance of SOM Rock-Eval pyrolysis provides insight into the composition of SOM and even into its structure. Compositional information relies on the hydrogen and the oxygen index (HI and OI) values, related to the $\mathrm{H}$ and $\mathrm{O}$ content of SOM, respectively. Structural information is less straightforward and relies on the shape of the $S 2$ peak and on its " $T_{\text {peak }}$ " value(s).

The present application of Rock-Eval pyrolysis to a large sample set shows that the method effectively allows one to follow the evolution of the humification process with increasing depth in soil profiles, i.e. the progressive disappearance of inherited biopolymers and the formation of humic substances. Other important features such as the extensive oxidation that usually affects SOM in podzols, are also clearly evidenced. 


\section{References}

Adams \& Faure, 1996

Adams, J., Faure, H., 1996. Changes in moisture balance between glacial and interglacial conditions: influence on carbon cycle processes. In: Brandson, J., Brown, A.G., Gregory, K. J. (Eds.), Global Continental Changes: The Context of Palaeohydrology. Geological Society Special Publication. 115, pp 27-42.

Anderson, 1979

Anderson, H.A., 1979. Spodic horizon humus. In: Migrations organo-minérales dans les sols tempérés. Colloques internationaux du Centre National de la Recherche Scientifique no. 303. Editions du CNRS, Paris, pp. 269-273.

Andreux et al., 1986

F. Andreux, P. Faivre, M. Bonne

Nature et dynamique des matières organiques impliquées dans les processus de podzolisation

D. Righi, A. Chauvel (Eds.), Podzols et Podzolisation, AFES and INRA, Plaisir and Paris (1986), pp. 119-130

Ariztegui et al., 1996

D. Ariztegui, P. Farrimond, J.A. McKenzie

Compositional variations in sedimentary lacustrine organic matter and their implications for high Alpine Holocene environmental changes/lake St Moritz Organic Geochemistry, 24 (1996), pp. 453-461

Balesdent, 1996

J. Balesdent

The significance of organic separates to carbon dynamics and its modelling in some cultivated soils

European Journal of Soil Science, 47 (1996), pp. 485-493

Batjes, 1996

N.H. Batjes

Total carbon and nitrogen in the soils of the world

European Journal of Soil Science, 47 (1996), pp. 151-163

Bigois et al., 1986

Bigois, M., Novat, C., Le Perchec, P., Fixari, B., 1986. Procédé et dispositif de détermination de la quantité d'au moins un élément choisi parmi le carbone, l'hydrogène, le soufre et l'azote d'au moins deux fractions d'un échantillon de matière organique. Brevet No. 86/16 409.

Bodineau et al., 2002

G. Bodineau, N. Volland, I. Cousin, J.R. Disnar, L. Balbino, M. Brossard, A. Bruand Dynamique de la structure et caractéristiques des constituants organiques dans les ferralsols de la région du Cerrado (Brésil) 
P. Launeau, J. Girardeau, A. Cossard (Eds.), Proceedings of the 19th Réunion Annuelle des Sciences de la Terre, Faculté des Sciences et Techniques, Université de Nantes (2002), p. 68

Buillit et al., 1997

N. Buillit, E. Lallier-Vergès, J.R. Disnar, J.L. Loizeau

Changements climatiques et effets anthropiques au cours des deux derniers

millénaires attestés par l'étude pétrographique de la matière organique (Annecy, Le Petit Lac, France)

Bulletin de la Société Géologique de France, 168 (1997), pp. 573-583

Carter et al., 1997

M.R. Carter, D.A. Angers, E.G. Gregorich, M.A. Bolinder

Organic carbon storage and nitrogen stocks and storage profiles in cool, humid soils of eastern Canada

Canadian Journal of Soil Science, 77 (1997), pp. 205-210

van Cleve \& Powers, 1995

K. van Cleve, R.F. Powers

Soil carbon, soil formation, and ecosystem development

W.W. McFree, M.J. Kelly (Eds.), Carbon Forms and Functions in Forest Soils, Soil Science Society of America, Madison (1995), pp. 155-200

Copard et al., 2002

Y. Copard, J.R. Disnar, J.F. Becq-Giraudon

Erroneous maturity assessment given by Rock-Eval parameters (Tmax and IH) on highly mature wheathered coals

International Journal of Coal Geology, 49 (2002), pp. 57-65

Di-Giovanni et al., 1998

Ch. Di-Giovanni, J.R. Disnar, V. Bichet, M. Campy, B. Guillet

Geochemical characterization of soil organic matter and variability of a post detrital organic supply (Chaillexon lake, France)

Earth Surface Processes and Landforms, 23 (1998), pp. 1057-1069

Di-Giovanni et al., 1999

Ch. Di-Giovanni, J.R. Disnar, M. Campy, J.-J. Macaire

Variability of the ancient organic supply in modern humus

Analusis, 27 (1999), pp. 398-402

Di-Giovanni et al., 2000

Di-Giovanni, Ch., Disnar., J.R., Kéravis, D., Olivier, J.-E. 2000. How fossil organic matter gives information about modern mechanical weathering. In: Entering the Third Millenium with a Common Approach to Humic Substances and Organic Matter in Water, Soil and Sediments. Proc. IHSS 10. Association pour la Promotion du Génie des Procédés, Toulouse, pp. 699-702. 
Disnar, J.R., 1982. Etude expérimentale de la fixation de divers métaux sur une matière organique sédimentaire d'origine algaire. Maturation thermique des composés formés. Thèse d'Etat, Université d'Orléans.

Disnar, 1994

J.R. Disnar

Determination of maximum paleotemperatures of burial (MPTB) of sedimentary rocks from pyrolysis data on the associated organic matterbasic principles and practical application

Chemical Geology, 118 (1994), pp. 289-299

Disnar \& Trichet, 1984

J.R. Disnar, J. Trichet

The influence of various divalent cations $\left(\mathrm{UO}_{2}{ }^{2+}, \mathrm{Cu}^{2+}, \mathrm{Pb}^{2+}, \mathrm{Co}^{2+}, \mathrm{Ni}^{2+}, \mathrm{Zn}^{2+}\right.$, $\mathrm{Mn}^{2+}$ ) on thermally induced evolution of organic matter isolated from an algal mat Organic Geochemistry, 6 (1984), pp. 865-874

Disnar et al., 2001a

Disnar, J.R., Guillet, B., Karroum, M., Lottier, N., Bernier, N., Ponge, J.-F., 2001a. Organic matter dynamics in a dysmoder type thick forest humus under beech (Fougères, France). In: Abstracts Vol. 2, 20th International Meeting on Organic Geochemistry, Université Poincarré, Nancy, pp. 93-94.

Disnar et al., 2001b

Disnar, J.R., Copard, Y., Becq-Giraudon, J.-F., Laggoun-Défarge, F., 2001b. Erroneous coal maturity assessment caused by low temperature oxidation. In: Proceedings of the 11th International Conference on Coal Science, San Francisco, USA. US Department of Energy, National Energy Technology Laboratory (electronic publication).

Disnar et al., 2000

Disnar, J.R., Guillet, B., Kéravis, D., Massif, R., Di Giovanni, C., 2000. Soil organic matter (SOM) characterization by Rock-Eval pyrolysis: main classical parameters. In: Entering the Third Millenium with a Common Approach to Humic Substances and Organic Matter in Water, Soil and Sediments, Proceedings IHSS. Association pour la Promotion du Génie des Procédés, Vol. Toulouse, pp. 1211-1214.

Espitalite et al., 1977

J. Espitalié, J.L. Laporte, M. Madec, F. Marquis, P. Leplat, J. Paulet, A. Boutefeu Méthode rapide de caractérisation des roches mères, de leur potentiel pétrolier et de leur degré d'évolution

Revue de l'Institut Français du Pétrole, 32 (1977), pp. 23-42

Espitalite et al., 1984

J. Espitalié, K. Senga Makadi, J. Trichet

Role of the mineral matrix during kerogen pyrolysis

Organic Geochemistry, 6 (1984), pp. 365-382

Espitalite et al., 1985a

J. Espitalié, G. Deroo, F. Marquis

La pyrolyse Rock-Eval et ses applications; première partie

Revue de l'Institut Français du Pétrole, 40 (1985), pp. 563-579 
Espitalite et al., 1985b

J. Espitalié, G. Deroo, F. Marquis

La pyrolyse Rock-Eval et ses applications; deuxième partie

Revue de l'Institut Français du Pétrole, 40 (1985), pp. 755-784

Eswaran et al., 1993

H. Eswaran, E. van Den Berg, P. Reich

Organic carbon in soils of the world

Soil Science Society of America Journal, 57 (1993), pp. 192-194

FAO, 1994

FAO, 1994. World Reference Base for Soil Resources. Draft from Food and Agriculture Organization of the United Nations, Land and Water Development Division, Via delle terme di Caracalla, 00100-Roma, Italia.

Federer, 1982

C.A. Federer

Subjectivity in the separation of organic horizons of the forest floor

Soil Science Society of America Journal, 46 (1982), pp. 1090-1093

Guillet et al., 2001

B. Guillet, G. Achoundong, J. Youta Happi, V. Kamgang Kebeyene Beyala, J. Bonvallot, B. Riera, A. Mariotti, A. Schwartz

Agreement between floristic and soil organic carbon isotope $\left({ }^{13} \mathrm{C} /{ }^{12},{ }^{14} \mathrm{C}\right)$ indicators about forest invasion of savannas during the last century. Cameroon Journal of Tropical Ecology, 17 (2001), pp. 809-832

Guillet et al., 1988

B. Guillet, P. Faivre, A. Mariotti, J. Khobzi

The ${ }^{14} \mathrm{C}$ dates and ${ }^{13} \mathrm{C} /{ }^{12}$ ratios of soil organic matter as a means of studying the past vegetation in intertropical regionsexamples from Colombia (South America) Palaeogeography, Palaeoclimatology and Palaeoecology, 65 (1988), pp. 51-58

Jabiol et al., 1995

B. Jabiol, A. Brêthes, J.-F. Ponge, F. Toutain, J.-J. Brun

L'humus sous toutes ses formes

ENGREF, Nancy (1995)

Jocter-Montrozier \& Robin, 1988

L. Jocteur-Montrozier, A.M. Robin

Action de la faune du sol sur une litière de feuillu: application de techniques pyrolytiques à l'étude des modifications subies par une feuille de charme (Carpinus betulus) ingérées par Glomeris marginata

Revue d'Ecologie et de Biologie du Sol, 24 (1988), pp. 203-214

Karlen et al., 1997

D.L. Karlen, M.J. Mausbach, J.W. Doran, R.G. Cline, R.F. Harris, G.E. Schuman

Soil quality a concept, definition and framework for evaluation (a guest editorial)

Soil Science Society of America Journal, 61 (1997), pp. 4-10 
Lafargue et al., 1998

E. Lafargue, F. Marquis, D. Pillot

Rock-Eval 6 applications in hydrocarbon exploration, production and soil contamination studies

Revue de l'Institut Français du Pétrole, 53 (1998), pp. 421-437

Langford \& Blanc-Valleron, 1990

F.F. Langford, M.-M. Blanc-Valleron

Interpreting Rock-Eval data using graphs of pyrolyzable hydrocarbons vs. total organic carbon

American Association of Petroleum Geologists Bulletin, 74 (1990), pp. 799-804

Lo \& Cardott, 1995

H.B. Lo, B.J. Cardott

Detection of natural weathering of Upper Mc Alester and Woodford shale,

Oklahoma, USA

Organic Geochemistry, 22 (1995), pp. 73-83

Makadi Kimpanga, 1982

Makadi Kimpanga, S., 1982. Etude expérimentale des interactions entre matière organique-matrice minérale au cours de la pyrolyse. Thesis, Université d'Orléans.

Peters, 1986

K.E. Peters

Guidelines for evaluating petroleum source rocks using programmed pyrolysis

American Association of Petroleum Geologists Bulletin, 70 (1986), pp. 799-804

Robert, 1996

M. Robert

Le Sol: Interface dans l'Environnement, Resource pour le Dévelopement

Masson, Paris (1996)

Schnitzer et al., 1994

M. Schnitzer, H. Kodama, H.-R. Schulten

Mineral effects on the pyrolysis-field ionization mass spectrometry of fulvic acid

Soil Science Society America Journal, 58 (1994), pp. 1100-1107

Schwartz et al., 1986

D. Schwartz, B. Guillet, G. Villemin, F. Toutain

Les alios humiques des podzols tropicaux du Congoconstituants, micro-et ultrastructure

Pédologie, Ghent, 36 (1986), pp. 179-198

Schwartz, 1988

D. Schwartz

Some podzols on Bateke sands and their origins, People's Republic of Congo

Geoderma, 43 (1988), pp. 229-247

Sifeddine et al., 1995

A. Sifeddine, F. Laggoun-Défarge, E. Lallier-Vergès, J.R. Disnar, D. Williamson, F. Gasse 
La sédimentation organique lacustre en zone tropicale sud au cours des 36000 dernières années (Lac Tritrivakely, Madagascar)

Compte-rendus de l'Académie des Sciences, Paris, série (2a) (1995), pp. 385-391

Stevenson, 1982

F.J. Stevenson

Humus Chemistry: Genesis, Composition, Reaction

Wiley, New York (1982)

Zech \& Kogel-Knabner, 1994

W. Zech, I. Kögel-Knabner

Patterns and regulation of organic matter transformation in soils: litter decomposition and humification

E.-D. Schulze (Ed.), Flux Control in Biological Systems, Academic Press, San Diego (1994), pp. 303-334 